\title{
Comparing American and Ukrainian Library and Information Science Education
}

\author{
SVITLANA CHUKANOVA \\ Viktor Kytasty American Library, National University of Kyiv-Mohyla Academy, \\ Kyiv, Ukraine
}

Ukraine is in the process of modernizing its educational system. This process must incorporate the best foreign practices to support the Ukrainian educational model. Library and information science (LIS) in the United States presents the best example of implementing technologies in the bumanities. For that reason, Ukrainian higher educational establishments should pay attention to issues of integrating library science with information science.

KEYWORDS Library and information science education, library and information studies, LIS, Ukraine, Ukrainian, United States, American, USA

\section{INTRODUCTION}

Ukraine's current law On Higher Education, adopted in 2014, defines the main aim of a higher education establishment as "providing necessary conditions for people receiving higher education, and providing qualitative training for future specialists."1

As we know, the educational process is a multileveled and complicated activity. It consists of different stages. The self-study stage is considered to be one of the most important components of modern education. Libraries should be regarded as one of the main supporting institutions, since they focus on keeping and disseminating information necessary for the educa- :ional process. Librarians are very important participants in this process, so we need to pay attention to their professional training.

(C) Svitlana Chukanova

Address correspondence to Svitlana Chukanova, MA, Coordinator, Viktor Kytasty American Library, National University of Kyiv-Mohyla Academy, 8/5 Voloska Str., Kyiv, 04070, Ukraine. E-mail: chukanovaso@ukma.kiev.ua

In order to improve the quality of professional training in general in Ukraine and librarians' training in particular, it is helpful to analyze positive international experience. Likewise, examining the quality of higher education in Ukraine is closely connected to the study of international experience. In the field of library and information science (LIS), Ukraine could benefit from looking at progressive ideas and technologies developed in the United States. The Ukrainian education system is quite different from the American one, but with the world continuously progressing, we must consider education as a global and overarching process. ${ }^{2}$ 


\section{COMPARISON OF UKRAINIAN AND AMERICAN APPROACHES TO LIS EDUCATION}

The tradition of library education in Ukraine has Russian and Soviet origins. Library science exists separately from information science in present-day Ukraine, although now we can observe a tendency for Ukraine to become more actively involved with modern information society. Unlike American LIS education, Ukrainian library education is regulated by the government- specifically by the Ministry of Education and Science, and the Ministry of Culture. A succinct comparison of the two LIS educational systems can be seen in Table 1.

\section{SUGGESTIONS FOR MODERNIZING THE LIS CURRICULUM IN UKRAINE}

Disciplines of an informational character are very important to library science throughout the world. Ukraine is currently undergoing a process of modernizing its system of higher education. Ukrainian legislation on education is also in the process of being modernized. Since Ukraine wants to join the world scholarly and educational community, we must be aware of modern tendencies and technologies as applied to information management and library science. Leading Ukrainian education experts regard educational quality as an indicator of high social, cultural, and economic growth. The world community pays great attention to issues of professional competencies. Ukraine does also. ${ }^{3}$

In order to accelerate Ukraine's integration into the world educational and scholarly community, especially in the field of LIS, we need to revise some important disciplines in the curriculum of higher educational establishments that prepare specialists in LIS. We will look at disciplines that are quite new to Ukrainian librarianship but are very important for its further development. In our opinion, the following disciplines should be included (using 
Comparing LIS Education in UA and USA 201

TABLE 1 Comparison of LIS education in the US and Ukraine (general data).

Ukrainian educational

\begin{tabular}{|c|c|c|}
\hline Criterion & model & American educational model \\
\hline Degrees granted & $\begin{array}{l}\text { Bachelor (BA), Specialist, } \\
\text { Master (MA, MS), Doctor } \\
\text { of Philosophy (PhD), } \\
\text { Doctor of Science }\end{array}$ & $\begin{array}{l}\text { MA and MS primarily, but there are } \\
\text { some library professions of a } \\
\text { technical character that require } \\
\text { only AS, AA, or BA, BS. Also MBA, } \\
\text { PhD, Doctor of LIS. }\end{array}$ \\
\hline $\begin{array}{l}\text { Structure of the } \\
\text { curriculum }\end{array}$ & $\begin{array}{l}\text { Close relation to } \\
\text { documentary science. } \\
\text { The curriculum is } \\
\text { approved by the higher } \\
\text { educational } \\
\text { establishment } \\
\text { authorities only, } \\
\text { because there is no } \\
\text { structural department } \\
\text { like a library school in } \\
\text { Ukraine. }\end{array}$ & $\begin{array}{l}\text { Close relation to information } \\
\text { science. The curriculum is } \\
\text { designed by the teaching staff and } \\
\text { students of the library school and } \\
\text { partially regulated by the higher } \\
\text { educational establishment. }\end{array}$ \\
\hline $\begin{array}{l}\text { Forms of academic } \\
\text { instruction }\end{array}$ & $\begin{array}{l}\text { Lectures, seminars, } \\
\text { workshops, mixed-type } \\
\text { forms. All the forms are } \\
\text { regulated by the higher } \\
\text { educational } \\
\text { establishment }\end{array}$ & $\begin{array}{l}\text { All forms are of mixed type and } \\
\text { regulated by the course's } \\
\text { instructor. }\end{array}$ \\
\hline $\begin{array}{l}\text { Level of integration } \\
\text { between } \\
\text { information } \\
\text { science and library } \\
\text { science }\end{array}$ & $\begin{array}{l}\text { Currently at the initial } \\
\text { level }\end{array}$ & Very high \\
\hline $\begin{array}{l}\text { Approach to } \\
\text { professional } \\
\text { development }\end{array}$ & $\begin{array}{l}\text { According to current } \\
\text { Ukrainian legislation, } \\
\text { with the support of } \\
\text { Ukrainian Library } \\
\text { Association }\end{array}$ & $\begin{array}{l}\text { According to the American Library } \\
\text { Association's Standards for } \\
\text { Accreditation of Master's Programs } \\
\text { in Library and Information Studies }\end{array}$ \\
\hline $\begin{array}{l}\text { Influence of } \\
\text { professional } \\
\text { organizations }\end{array}$ & $\begin{array}{l}\text { Strong influence of ULA } \\
\text { on professional } \\
\text { development }\end{array}$ & $\begin{array}{l}\text { Strong influence of ALA on } \\
\text { professional development and } \\
\text { accreditation process in professional } \\
\text { education }\end{array}$ \\
\hline
\end{tabular}

the American approach ${ }^{4}$ as a model), since they are vital for LIS studies in Ukraine:

- Information literacy (first year of BA program)

- Information-seeking behavior (first year of BA program)

- Information architecture (second year of BA program)

- Structuring information with XML (third year of BA program)

- Computer network administration (third year of BA program)

- Metadata design (fourth year of BA program) 
Students who receive the BA or BS degree could enrich their knowledge of LIS with MA or MS programs. The following disciplines are suggested as additions to the curriculum of MA and MS LIS programs in Ukraine:

- Bibliometrics and scientometrics

- Use of integrated library systems in libraries

The above-mentioned disciplines should be regarded as core courses. They could be supplemented by such electives as the following:

- Human-computer interaction

- Online reference services for undergraduate programs

- Digital libraries and information retrieval in the social context

These subjects could be offered as topics or modules within an IS course, rather than separately. Whichever way they are offered, however, they should be integrated with existing disciplines.

An introduction to information studies course should be offered at the undergraduate level, and can encompass modules in information literacy and information-seeking behavior. ${ }^{5}$

Since we are attempting to construct a model curriculum in LIS, we should mention that what we are proposing comprises recommendations only; they can be modified on the basis of further study. We decided to regard the above-mentioned courses as separate disciplines with the number of credits calculated according to the standards of master's programs in LIS developed by the American Library Association (ALA). ${ }^{6}$

\section{DESCRIPTION OF NEW DISCIPLINES TO BE INCLUDED IN THE LIS CURRICULUM}

The recommendations included in this section may be used as a template for constructing LIS curricula in Ukraine. Let us examine each core discipline in the template. A course in information-seeking behavior would be intended to teach students how to acquire the necessary skills to search for information in different library catalogs, databases of scholarly information, indexes, etc. Such a course would involve 3-4 credits and consist of practical and theoretical parts, structured as in Table 2.

The evaluation of skills acquired during the course would include preliminary and final evaluations based on workshops, practical class lessons on the computer, and a final exam.

A course in information architecture would teach LIS students how to structure and design web pages and other online services in order to enhance 
TABLE 2 Distribution of instruction formats for Format

Lectures

Hybrid (lectures and practical instruction) Practical

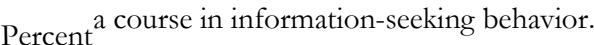

$15 \% 15 \%$

$70 \%$ (of which $30 \%$ would be individual study)

the user interface and functional information systems competently and efficiently. In addition, the course would teach the architectural principles underlying work in the digital environment.

In order to understand the essence of this discipline we need a more detailed definition of the term information arcbitecture. Peter Morville and Louis Rosenfeld define it as including the following:

- The structural design of shared information environments

- The combination of organization, labeling, search, and navigation systems within websites and intranets

- The art and science of shaping information products and experiences to support usability and findability

- An emerging discipline and community of practice focused on bringing principles of design and architecture to the digital landscape ${ }^{7}$

The course should combine theoretical and practical formats (see Table 3). In general it would encompass 3 credits. Students would be evaluated during the class on the basis of practical tasks, module tests, and self-study work. Final evaluation would be based on a final examination and a practical task performed on the computer.

A course in structuring information using eXtensible Markup Language (XML) would develop practical skills in XML. Students would learn how to apply the main XML principles in libraries, as well as in web design, content management, metadata processing, and data interchange. ${ }^{8}$

The best way to launch a course in structuring information using XML in Ukrainian higher educational establishments would be to provide it in hybrid form (without a clear distinction between the theoretical and practical parts), since this discipline requires more practical elements than theoretical, due to its specific character. The best number of credits for this course is

TABLE 3 Distribution of instruction formats for a course in information architecture.

\begin{tabular}{|c|c|}
\hline Format & Percent \\
\hline Lectures & $35 \%$ \\
\hline Practical & $65 \%$ (of which $30 \%$ would be individual study) \\
\hline
\end{tabular}


3. Self-study work for the course should be no less than $40 \%$. Evaluation methods for this course would be similar to those listed above for courses in information-seeking behavior and information architecture.

Undergraduate LIS programs would also require courses in network administration and metadata design. The latter is very important to the professional who works with digital libraries. The number of credits suggested for these courses is 3 . The instruction format for these courses should be of hybrid type, and self-study work should be no less than $35-45 \%$. The evaluation methods for them would be the same as for the courses described earlier.

The importance of the courses mentioned here is supported by the fact that the majority of modern libraries use automated integrated library systems (ILS) and try to provide their users with Internet and electronic services. Libraries compete with the many other institutions that offer similar services. ${ }^{9}$ The process of information obsolescence has become faster; thus librarians need to meet current requirements and know how to apply their knowledge effectively.

Since library science is integrated into information science in the United States, rejection of BA and BS programs is justified. The approach to choosing a profession is dramatically different in the US than in Ukraine. In Ukraine the bachelor's program is considered basic and has a general nature, while the master's program has a philosophical basis. The US bachelor's program is geared toward practitioners, while the master's program is geared toward future researchers.

In the US the current attitude toward the profession of librarian involves creativity, intellectual work, and effective management. Sometimes the choice of a bachelor's program depends on the student's desire to select a library master's program later. Such students usually choose undergraduate programs in computer science, linguistics, science, and history. A student who graduated from a bachelor's program in computer science would have an advantage, since the information component of the master's program in LIS is so important; it would make a significant impact on the entire learning process for this program.

In Ukraine, librarianship-despite the powerful influence of information disciplines-still does not have ties sufficiently close to information science to enable the two fields to be merged. That is why we believe that at this stage, abolishing the undergraduate program is inappropriate in Ukraine, even if other aspects of the American educational approach in library education are implemented. ${ }^{10}$

We presume that knowledge gained during undergraduate studies would provide a foundation for graduate studies; that is why the LIS curriculum should be enriched with disciplines with practical applications, in addition to theoretical courses (those with an academic or research component).

Another important course for LIS studies is bibliometrics and scientometrics, because evaluation of academic performance has become such a vital issue for modern scholars. Citation analysis should be included as well. ${ }^{11}$ Modern librarians should learn from their patrons how academic work is evaluated and 
how to define the rating of a scholarly publication or journal. The structure of the course should include the following components:

- History of bibliometrics

- Lotka's law

- Zipf's law

- Bradford's law

- Information sources analysis

- Citation analysis

- Practical applications of citation analysis and bibliometrics

- Future of bibliometrics and citation analysis

The course itself should have 4 credits. Preliminary evaluation of students' knowledge of the material would include written and oral surveys, and the final evaluation would be performed with an oral examination together with one practical task. The course would have the format shown in Table 4.

The number of Ukrainian libraries currently using ILSs is on the increase. Thus, it is important to implement a course in using ILSs. This course can consist of $30 \%$ theoretical and $70 \%$ practical material. Along with this discipline the issue of information literacy should be considered as well. Methods of evaluation in this course would be similar to those outlined earlier in this article.

As we see, the proportion of theoretical to practical components in each course is fairly uniform-meaning that the proposed classes are geared toward the practical issues that need to be covered in order to allow the future librarians to work effectively. The number of credits for these classes can vary from 2 to 4 , so that each institution can adapt the proposed model for its own curriculum.

In Figure 1 we see a visual summary of how to create an LIS curriculum that includes disciplines in information science.

TABLE 4 Distribution of formats of instruction for a course in bibliometrics and scientometrics.

\begin{tabular}{ll}
\hline Format & Percent \\
\hline Lectures & $45 \%$ \\
Practical & $55 \%$ (of which $25 \%$ would be individual study) \\
\hline
\end{tabular}




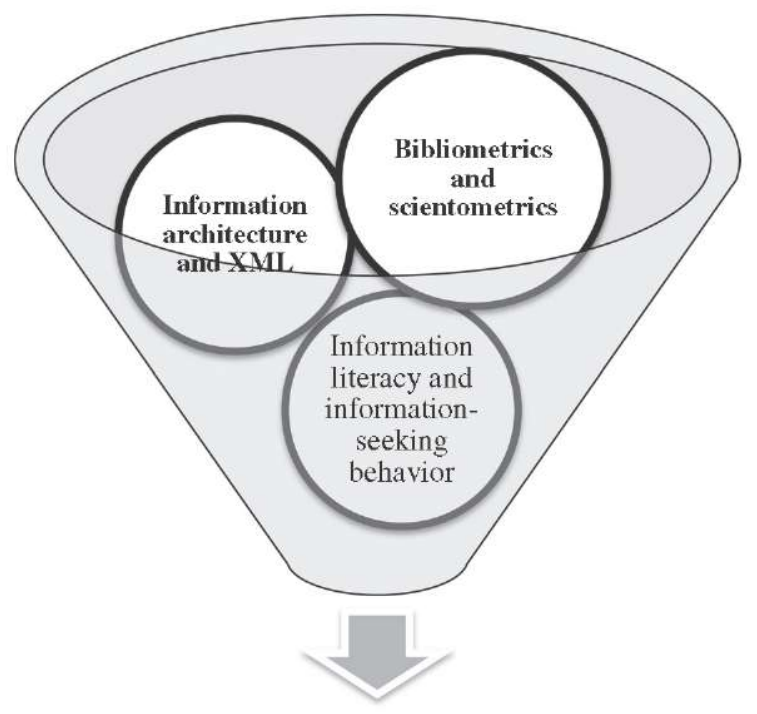

LIS curriculum modernization template

FIGURE 1 Compiling an LIS curriculum that includes information science disciplines.

Let us briefly discuss the main highlights in American LIS education. The typical curriculum in library and information science in the US, as exemplified by the MA LIS program in the University of Washington's Information School (iSchool), includes the following disciplines ${ }^{12}$ :

- Basic principles of reference service

- Cataloging

- Principles of acquisition

- School library service

- Minor courses, e.g., archival service, management, and philosophy of education

- Required courses of an information science nature:

- Creation and management of databases

- Web design

- Information architecture

The iSchool pays great attention to students' research activities; thus during the evaluation process, this aspect is considered to be the most important. ${ }^{13}$ The research methods used by the MA LIS program students include the following:

- Empirical methods

- Content analysis 
- Historiography

- Interview

As previously mentioned, research work is one of the most important aspects of LIS education. Among the main subjects actively studied by library and information researchers in the US are:

- Information-seeking behavior

- Copyright

- Digitizing rare publications

- Service analysis

- Web design

- Collection management

- Cloud technologies

- Metadata description

Speaking about Ukraine, we must admit that there is no such level of library education here at present. The main difference between US and Ukrainian LIS education systems is the absence of a BA degree in LIS in the US, while in Ukraine there is still a BA degree in LIS. In Ukraine there are no requirements to have practical experience before entering a higher educational establishment to receive LIS education; at the same time, in the United States it is obligatory to have practical experience before entering library school. As a result, American librarians receive better education and better preparation for real practical work. The Ukrainian Library Association has not established education standards for future library specialists; thus the curriculum for LIS studies in Ukraine does not always meet requirements for the modern library profession. We propose that in Ukraine the integration process of library science with information science be made gradually, by means of step-by step addition of information science courses into the curriculum at higher educational establishments that prepare future librarians.

\section{CONCLUSION}

In summary, we have seen that with the development of scholarship and technology, library education has evolved. The modern world has created new requirements for the profession of librarian, enriching it with new elements. From examining the system of library education in Ukraine, we have concluded that the need for information science became crucial at the end of 1980s and beginning of 1990s in Ukraine. ${ }^{14}$ Library science is an interdisciplinary subject; thus it draws on pedagogy, ethics, economy, sociology, and psychology. Its development also depends a great deal on the influence of information and communication technologies. 
Our research comparing the library education systems of Ukraine and the United States has led us to conclude that the main principles of library activities as a social institution in Ukraine and the US are similar, as are the main approaches to library science. These approaches have identical vectors, although they are different in terms of the librarian's role and the vision of libraries. If in Ukraine the library as a social institution is regarded as the main player, in the US special attention is paid to the professional librarian, the one who works in a library or in another information institution. Thus by looking at the common vector we can observe the differences in approach to its realization in terms of social communication.

The modern Ukrainian library education system is now moving to include in the LIS curriculum the following disciplines: documentary science, information analytics, information science, etc.- - thus adapting the LIS curriculum to the requirements of modern society.

Library science is currently undergoing a process of transitioning from the humanities to the social science sphere. This process is inevitable. Such a transition from one sphere to another must be reflected in the library education system. Today the issue of modernizing the LIS curriculum is crucial to Ukrainian society. That is why we are advocating the inclusion of courses in information science into the BA, BS, MA, and MS programs in library science in Ukraine. We also mentioned that Ukrainian librarianship now pays considerable attention to the matter of evaluating academic performance. This fact corroborates the need to implement such courses as bibliometrics, scientometrics, and citation analysis.

Examining and comparing educational approaches to training future professionals in librarianship in Ukraine and the United States, we can conclude that Ukraine has the potential to develop library education in the context of the innovations currently in progress, since it has all the prerequisites. In modern Ukrainian library education, as in any other field, it is necessary to use modern information and communication technologies and make innovative changes effectively. However, this approach involves redefining the role of libraries in society.

The main difference between library education in the United States and Ukraine is that the US is clearly aware of the need for training library staff and has made every effort to get the most out of the educational standards for this trend. ${ }^{15}$ Librarianship in the United States once existed as a separate field, ${ }^{16}$ while in Ukraine even before librarianship was included into the cultural sphere, it already was part of political education. That is why we can say that at the time libraries were shaped in Ukraine and the United States, the founders of the discipline evaluated the impact of media on society in different ways. In addition, the different approaches to library education in the two countries involve different overall structures for managing institutional autonomy and accreditation of programs.

Finally, we can say that the general educational model in the process of being implemented in Ukraine comes close to international standards. We draw this conclusion based on current Ukrainian legislation on higher education. The requirements for forms of instruction and curriculum are nearly at the international 
level. However, in the sphere of librarianship Ukraine still has a long way to go in order to meet modern world educational standards.

\section{ORCID}

Svitlana Chukanova (C) http://orcid.org/0000-0002-5717-5050

\section{NOTES}

1. Zakon Ukrainy "Pro vyshchu osvitu," [Law of Ukraine "On higher education"], Vidomosti Verkhovnoi Rady no. 37-38 (2004): 134. http://zakon4.rada.gosv.ua/laws/show/1556-18

2. See Svitlana Chukanova, "American Library Association-Crucial Element in Library and Information Science Education Management," Teoriia ta metodyka upravlinnia osvitoiu = Theory and Methods of Educational Management: Electronic Journal no. 2 (2014): 1-11. http://umo.edu.ua/images/ content/nashi_vydanya/metod_upr_osvit/v_15/19.pdf

3. Olena Lokshyna, ed., Monitoring iakosti osvity: stanovlennia ta rozvytok v Ukraini [Monitoring the quality of education: formation and development in Ukraine] (Kyiv, Ukraine: Ministerstvo osvity i nauky Ukrayiny, 2004), 4-6.

4. See, for example: University of Denver, Morgridge College of Education, "Library and Information Science Program Coursework Plan, Handbook Year 2013-2014," http://morgridge.du.edu/ wp-content/uploads/2013/04/Library-and-Information-Science-Program-2013_14-form.pdf

5. See Andy Barrett, "The Information Seeking Habits of Graduate Student Researchers in the Humanities," Journal of Academic Librarianship 31, no. 4 (2005): 324-331.

6. American Library Association, "Accreditation of Master's Programs in Library \& Information Studies" (Chicago, IL: American Library Association, Office for Accreditation, 2008), http://www.ala.org/ accreditedprograms/sites/ala.org.accreditedprograms/files/content/standards/standards_2008.pdf. Editor's note: ALA posted revised standards in June 2015, after this article was submitted. See the organization's page "Standards, process, policies, and procedures (AP3)," http://www.ala.org/accreditedprograms/ standards.

7. Peter Morville and Louis Rosenfeld, Information Architecture for the World Wide Web, 3rd ed. (Beijing; Sebastopol, CA: O'Reilly, 2007), 4.

8. An example of such a course is: Ron Gilmour, Regional Institute "XML in Libraries," offered through ALA's Library and Information Technology Association (LITA), http://www.ala.org/lita/learning/ regional/xmlinst

9. Kathleen de la Pena McCook, Opportunities in Library and Information Science Careers (New York, NY: McGraw-Hill, 2001), 60-88

10. See Vasyl Babych, "Do problem pidgotovky kadriv bibliotechno-informatsiinoi sfery" [Toward the problem of preparing staff in the library and information sphere], Bibliotechnaplaneta, no. 2 (2005): 5-11.

11. See John N. Olsgaard, ed., Principles and Applications of Information Science for Library Professionals (Chicago, IL: American Library Association, 1989), 3-37.

12. See, for example, University of Washington, Information School, Program Presentation for the Committee on Accreditation of the American Library Association, https://ischool.uw.edu/sites/default/ files/documents/mlis/MLIS_Accred_Report_2013.pdf (accessed 13 September 2013).

13. University of Washington, Information School, Program Presentation, 16.

14. See also Babych, "Do problem pidgotovky," 5-11.

15. See Chukanova, "American Library Association."

16. Rubin, Richard E. Foundations of Library and Information Science (New York, NY: Neal- Schuman Publishers, 2004), $300-353$. 